\title{
Cable and Wireless gains an uneasy foothold in Japan at last
}

Tokyo

Britain's Cable and Wireless, with the backing of the British and US governments, has gained a foothold in Japan in its battle to break the monopoly in transPacific telecommunications enjoyed by Kokusai Denshin Denwa (KDD) and American Telephone and Telegraph (AT\&T). Japan's Ministry of Post and Telecommunications has agreed in principle to let the British company and its US and Japanese partners lay a trans-Pacific cable. But the catch is that the Cable and Wireless consortium must join hands with an all-Japanese consortium that has totally incompatible plans.

Following the recent uproar in Britain and the United States over Japanese attempts to squeeze Cable and Wireless and US companies out of Japan's international telecommunications market (see Nature 326, 319; 1987), the ministry has made some concessions: foreign companies will be allowed to be on the board of directors and an equal share to Japanese partners in a new international telecommunications company to compete with KDD, and the new company can lay a trans-Pacific optical fibre cable, if all partners agree. But therein lies the rub. The ministry continues to insist that International Digital Communications Planning Inc. (IDC) established by the Cable and Wireless group must merge with the al!-

\section{UCSF space problem}

\section{San Francisco}

The University of California at San Francisco (UCSF) may have plenty of staff and money but space is proving harder to find.

Surrounded by a community that is intolerant of expansion, UCSF agreed in 1976 to limit expansion at its urban main campus and decentralize. But its latest plans, to convert office buildings to laboratories for the School of Pharmacy at Laurel Heights, about two miles from the campus, have run into opposition.

Despite a favourable environmental impact report, a community group filed suit to stop the conversion. The group picked out molecular parasitologist Nina Agabian, who planned to move from the Naval Bioscience Laboratory in Oakland. Rumours, strongly denied by the university, circulated that she is researching germ warfare for the Navy. Last September, a superior court judge upheld the environmental impact report. Now, UCSF is awaiting the outcome of an appeal by the neighbourhood group. If the court rules in favour, it will start the move next month.

Marcia Barinaga
Japanese consortium International Telecom Japan Inc. (ITJ) before a licence application to begin service will be considered. A meeting between executives of IDC and ITJ on 1 May failed to agree on a merger plan put forward by Japan's Federation of Economic Organizations (Keidanren) and only served to emphasize the difference between the groups.

Whereas IDC proposes to lay its own cable between Japan and Alaska, ITJ intends to lease circuits on Intelstat satellites and a trans-Pacific cable (TPC-3) to be laid by KDD and AT\&T in 1988. IDC will agree to a merger only if ITJ accepts the Japan-Alaska cable plan, and ITJ says the cable should not be a prerequisite for establishing the new company. The two consortia also failed to resolve the question of equity shares. ITJ calls for equal shares for all eight Japanese and foreign partners; IDC maintains it is necessary to form a "core group" of two of three companies holding most shares effectively to manage the firm.

Behind these disagreements lies a much bigger battle between the world's telecommunications giants. The JapanAlaska cable is part of Cable and Wireless's plan to build a "global digital highway" of optical fibre cables linking Europe, America and the Far East to compete with networks laid by KDD, AT\&T and British Telecom.

On 22 April, shortly after Japan's Ministry of Post and Telecommunications indicated conditional approval for IDC's cable, the US Federal Communications Commiss granted permission for Pacific Telecom Cable (a joint venture of Cable and Wireless and Pacific Telecom of the United States) to lay the trans-Pacific cable from Alaska. Two days later, KDD and AT\&T agreed on a joint survey for laying yet another trans-Pacific cable (TPC-4), even though KDD has been maintaining all along that there is sufficent demand to justify IDC's cable.

TPC-4 is part of a more grandiose plan to link Japan, Australia, New Zealand and the United States via a gigantic loop of optical fibre cables stretching around the Pacific rim that will be laid by KDD, AT\&T and telecom companies from Australia and New Zealand. KDD's president, at a press conference last Friday, even invited Cable and Wireless to participate in the laying of TPC-4. But although not without precedent - Cable and Wireless is cooperating with KDD and AT\&T in laying a Hong Kong-Japan optical fibre cable - Cable and Wireless seem likely to reject the offer as it has already turned down an option on TPC-3.

David Swinbanks

\section{Nuclear safety lesson}

\section{London}

BRITAIN's Nuclear Installations Inspectorate has not been able adequately to study the lessons of the Chernobyl accident because of staff shortages, according to its chief inspector, Eddy Ryder. He told the House of Commons Select Committee on Energy last week that nuclear safety inspectors cannot keep up with international developments because of lack of staff.

The inspectorate has 15 per cent less than its full complement of 120 inspectors, and finds it difficult to attract more staff because of its salary scale. Its limited resources or concentrated on the safety of operating nuclear reactors.

K.J.

\section{$£ 50 \mathrm{~m}$ AIDS fund aim}

\section{London}

THE fight against AIDS is to be boosted by a new government-backed charity which aims to raise $£ 5$ million over two years. Robert Maxwell, chairman of Mirror Group newspapers, will be chief fundraiser and a national AIDS trust, chaired by Sir Austin Bide, president of Glaxo Holdings, will spend the money.

Norman Fowler, Secretary of State for Social Services, stressed that the move is not a substitute for government action, and a coordinated response from both the voluntary sector and the government is essential.

S.J.H

\section{Shuttle widow sues}

\section{Washington}

THE widow of pilot Michael J. Smith, killed in the explosion of the space shuttle Challenger, has filed a $\$ 1,500$ million lawsuit against Morton Thiokol Inc., makers of the defective rocket booster; the US government; and Laurence Mulloy, head of NASA's rocket booster programme at the time of the accident.

The families of four of the seven astronauts killed in the accident have accepted compensation from NASA and Thiokol. One other family is suing Thiokol. The new lawsuit accuses Thiokol and NASA of "reckless disregard for human life". A.A.

\section{Blood products lab}

London

A NEW £55-million plasma-processing laboratory which opened last week will see England and Wales self-sufficient in Factor VIII, the product used to treat haemophiliacs, by 1989. A new high-temperature process will inactivate hepatitis non-A non-B and AIDS viruses.

For the first time in the United Kingdom, this drive to produce Factor VIII is expected to lead to surplus production of other plasma products which could be sold. As the Blood Products Laboratory obtains all its plasma from voluntary donations, it stresses that it will not be exploited for commercial purposes.

S.J.H. 